\title{
POLITIKK
}

\section{Når nordområdene lever sitt eget liv}

\author{
Torbjørn Pedersen \\ Professor, Nord universitet
}

\begin{abstract}
Sammendrag
I 2005 definerte den norske regjeringen nordområdene som sitt viktigste politiske satsingsområde, og satsingen var et resultat av flere faktorer, eller drivere. Mange av de opprinnelige driverne har imidlertid siden falt bort. Knapt noen snakker lenger om nordområdene som «Europas viktigste petroleumsprovins»; Sjtokman-feltet, som også norske selskaper og politikere higet etter den gang, er lagt på is; den transarktiske skipsfarten har floppet; NATOs nordlige flanke gikk likevel ikke i glemmeboken; og de fleste utestående jurisdiksjonsspørsmål fra den gang er blitt løst. Så hva er det da som holder nordområdesatsingen gående $\mathrm{i}$ dag, etter at flere av de viktigste driverne er falt fra? Dette kapitlet lanserer tre ulike forklaringer: 1) Nordområdebegrepet og -satsingen opprettholdes som såkalte condensation symbols fordi de skaper begeistring eller forventninger i befolkningen; 2) nordområdesatsingen har skapt strukturer som legitimerer og opprettholder seg selv, slik at satsingen har begynt å leve sitt eget liv; og 3) nordområdesatsingen kan forklares og forsvares rasjonelt med et nytt sett med drivere.
\end{abstract}

Nøkkelord: Arktis • internasjonale regimer • utenriks- og sikkerhetspolitikk $\cdot$ symbolpolitikk

\section{Innledning}

Nordområdene etablerte seg høyt på den politiske dagsordenen i løpet av første halvdel av 2000-tallet og har siden satt sitt preg på norsk politikk. Regionen ble i Stoltenberg II-regjeringens første regjeringserklæring, fra 2005, utpekt som «Norges

\footnotetext{
^Kontaktinformasjon: torbjorn.pedersen@gmail.com

(C)2018 Torbjørn Pedersen. This is an Open Access article distributed under the terms of the Creative Commons Attribution 4.0 International License (http://creativecommons.org/licenses/by/4.0/), allowing third parties to copy and redistribute the material in any medium or format and to remix, transform, and build upon the material for any purpose, even commercially, provided the original work is properly cited and states its license.

Citation:Torbjørn Pedersen (2018). Når nordomrädene lever sitt eget liv, 76(3): 140-158. http://dx. doi.org/10.23865/intpol. v76.1122
} 
viktigste strategiske satsningsområde»(Stoltenberg II-regjeringen 2005). Europakartet ble snudd på hodet: Barentshavet havnet i sentrum, med det europeiske kontinentet i bakgrunnen (figur 1). Her lå Norges største muligheter og utfordringer. Regionen skulle bli "Europas viktigste petroleumsprovins», og utenriksminister Jonas Gahr Støre siterte stadig fra Rolf Jacobsens dikt «Nord» i sine offentlige opptredener. Diktet innledes med «Se oftere mot nord» og avsluttes med «Det meste er nord» (Jacobsen 1985). Stoltenberg II-regjeringen fastholdt at nordområdene var Norges viktigste strategiske satsningsområde også i sin andre periode, som ble innledet i 2009 (Stoltenberg II-regjeringen 2009).

Den etterfølgende Solberg-regjeringen bruker også store ord om nordområdene og beskrev ved tiltredelsen i 2013 regionen som det viktigste interesseområdet

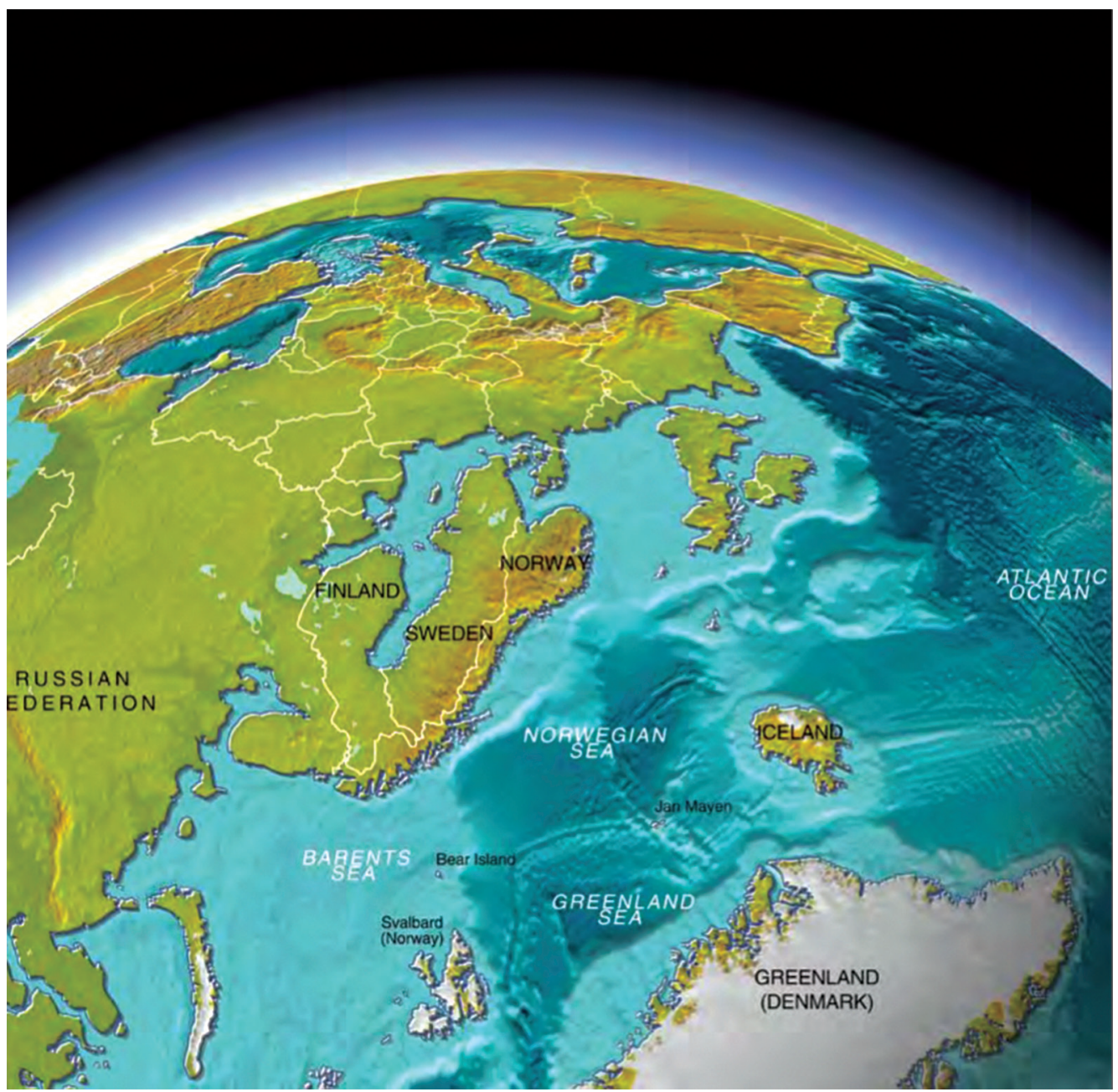

Figur 1: Nordområdene i sentrum? (faksimile fra Stoltenberg II-regjeringens nordområdestrategi 2006). 
i utenrikspolitikken (Solberg-regjeringen 2013). Solberg \& co. har så langt presentert en hel rekke med strategidokumenter relatert til nordområdene: Nordkloden (2014) og Nordområdestrategi: Mellom geopolitikk og samfunnsutvikling (2017), i tillegg til stortingsmeldingene Svalbard (2016) og Hav i utenriks- og utviklingspolitikken (2017). «Regjeringen har i 2017 lagt fram en ny ambisiøs nordområdestrategi, ny havstrategi og den første stortingsmeldingen om hav i utenriks- og utviklingspolitikken. Vi er i full gang med å følge opp alle disse initiativene,» sa utenriksminister Børge Brende gjennom pressemeldingen «Fortsatt satsing i nord» da Regjeringen presenterte sitt forslag til statsbudsjett for 2018 (Utenriksdepartementet 2017).

«Nordområdene» viser $\mathrm{i}$ denne sammenheng ikke til et definert geografisk område, siden begrepet mildt sagt har vært dynamisk siden det dukket opp på 1970-tallet, men en vag referanse til Norges nordligste landsdel og/eller ulike nærområder i nord (Hønneland \& Rowe 2010; Pedersen 2011; Skagestad 2017, 2014, 2009).

Spørsmålet som denne artikkelen reiser er: Hva var det som utløste den strategiske satsingen på nordområdene tidlig på 2000-tallet, og hva er det som holder politikkområdet gående $i$ dag? Svaret viser seg å være tankevekkende. Mange av de aller mest sentrale driverne, som definerte og plasserte nordområdene høyt på dagsordenen på begynnelsen og midten av 2000-tallet, har siden falt fra. Nordområdepolitikken lever videre - uavhengig av faktorene som skapte og formet den i utgangspunktet.

Denne studien skisserer tre mulige forklaringer på at nordområdesatsingen lever videre:

1) Symbolpolitikk. Nordområdene har blitt et politisk symbol som opprettholdes og pleies i kraft av å skape engasjement og positive forventninger.

2) Institusjonalisme. Nordområdesatsingen har fått regime- eller institusjonslignende strukturerer som redefinerer og legitimerer seg selv.

3) Politisk realisme. Nordområdesatsingen kan fortsatt forklares rasjonelt ut fra et sett med andre og nye drivere.

For det første søker denne artikkelen å identifisere de viktigste driverne som ble vektlagt i utformingen av nordområdepolitikken i første halvdel av 2000-tallet, det vil si frem til 2006. Opptakten til nordområdesatsingen var en offentlig utredning, NOU-rapporten Mot nord! (NOU 2003: 32) fra det såkalte Orheim-utvalget, og en offentlig debatt, som utgjør en viktig del av datagrunnlaget. Satsingen har videre kommet til uttrykk både gjennom Stortingsmelding 30 (2004-2005) Muligheter og utfordringer $i$ nord, fremlagt av Bondevik II-regjeringen i april 2005, Stoltenberg II-regjeringens tiltredelseserklæring fra oktober 2005 og Regjeringens nordområdestrategi (Utenriksdepartementet), som ble presentert av Stoltenberg II-regjeringen i desember 2006. NOU-en, det offentlige ordskiftet, tiltredelseserklæringen og de to strategidokumentene gir et godt bilde av hvilke utviklingstrekk og forventninger som ble vektlagt da ulike regjeringer valgte å løfte nordområdene høyt på den politiske agendaen og erklærte regionen som et betydelig satsingsområde. 
For det andre vil artikkelen gjøre opp status med disse driverne og se på hvorvidt disse fortsatt kan sies å forklare dagens nordområdepolitikk. Kilder her inkluderer rådata, som seilingsstatistikk og råvarepriser, men også en rekke publikasjoner, både mediebidrag og sentrale vitenskapelige arbeider. Norsk nordområdepolitikk har allerede vært gjenstand for en rekke studier (se f.eks. Hønneland 2017; Hønneland \& Rowe 2010; Pedersen 2011; Rowe 2014; Skagestad 2017, 2014, 2009). Andre har gjort opp status for de ulike driverne som også denne studien går inn på, for eksempel knyttet til utsiktene for transarktisk skipsfart (f.eks. Lasserre 2014; Lasserre et al. 2016; Moe 2015; Moe 2014) og petroleumsvirksomhet (f.eks. Harsem, Eide \& Heen 2011; Henderson \& Loe 2016; Keil 2017). Det er følgelig skrevet mye om relaterte og relevante emner, selv om ingen tidligere studier har sett på en nordområdesatsing som har revet seg løs fra sine opprinnelige drivere.

For det tredje vil denne artikkelen skissere mulige forklaringer på hvordan dette politikkområdet kan opprettholdes og leve videre, uavhengig av helt sentrale drivere som førte til at det ble et satsingsområde i utgangspunktet. Denne delen av analysen vil trekke veksler på teorier fra ulike disipliner, inkludert internasjonale relasjoner (IR), organisasjonsteori og politisk teori.

\section{Teoretiske tilnæmringer}

Tre ulike sett med teorier og/eller teoretiske retninger vil bli trukket inn i den avsluttende analysen av hva som holder liv i nordområdesatsingen i dag.

Den første teoretiske forklaringen er relatert til symbolpolitikk, i all hovedsak slik den er presentert i Murray Edelmans klassiske arbeid The Symbolic Uses of Politics (1985 [1964]). Her vektlegges de symbolske sidene av politisk språk og politiske handlinger. «Et symbols betydning kan ikke utledes fra symbolet, men fra observatørene og deres sosiale situasjon,» ifølge Edelman (1985: 200). Et sett med symboler, såkalte condensation symbols, kjennetegnes ved at de vekker følelser, som for eksempel patriotisme, forhåpninger eller angst. De rommer både tvetydighet og affeksjon, og de blir gierne sterkere og mer virkningsfulle jo mer tvetydige og følelsesladde de er (Edelman 1985).

Språk er et sentralt element i symbolpolitikken og er egnet til å engasjere "massene». Det mest effektive politiske språket preges altså ikke av nøyaktighet eller presisjon, snarere tvert imot:

Indeed, the most commonly used and most abstract terms are, naturally enough, those that reassure the anxious that the "public interest" or the "national security" or the "national health and safety" are being protected. The words mean different specific things to different groups, and for that reason are generally efficacious. (Edelman 1985: 116)

Og videre:

The propagandist whose verbalizations are most intensely embraced is the one who finds a formulation that evokes and synthesizes a large number of experiences of concern to his audience. (Edelman 1985: 124) 
Det er ikke dermed sagt at elitene nødvendigvis forsøker å manipulere eller bedra massene. Ifølge Edelman er symbolbruken like gjerne et uttrykk for den sosiale rollen som politikere spiller (Edelman 1985: 20). Et noe lignende resonnement er ført av blant andre Jon Elster, i hans beskrivelse av hvordan elitene appellerer til sosiale normer. «Normenes kraft springer ut av den følelsesmessige tonaliteten som gir dem et grep om sinnet,» fremholder Elster (1989: 128).

Den andre teoretiske forklaringen knytter seg til institusjonalisme, og da særlig til arbeider om hvordan både formelle og uformelle strukturer opprettholder og legitimerer seg selv når de først er etablert. Sosiologen Alberto Melucci forklarer hvordan organisasjoner kan bli selvoppholdende og bevege seg bort fra og uavhengig av sine opprinnelige mål:

The organizational apparatus develops specific interests of its own which do not necessarily coincide with the general interests of the movement, and tend to acquire relative priority. Preservation of organizational structure, or of positions, rules, and procedures, becomes the principal goal of those who perform functional roles within the organization. (Melucci 1983: 314)

Tankegodset, som gjerne assosieres med historisk institusjonalisme, er også videreført i internasjonal regimeteori innenfor disiplinen internasjonale relasjoner. Stephen Krasner viser for eksempel til regimers evne til «å overleve de fundamentale kausalfaktorene som førte til at de ble dannet i utgangspunktet» (Krasner 1983b: 357). Internasjonale regimer forstås her som «prinsipper, normer, regler og beslutningsprosedyrer som aktørers forventinger samles omkring innenfor et gitt saksfelt» (Krasner 1983a: 1). Regimer involverer gjerne undergrupper av medlemmene i det internasjonale samfunn, som regel byråkrater, ifølge Oran Young (1989). Regimers overlevelsesevne og integrasjon kan knyttes til flere faktorer, og en tidlig neofunksjonalist som Ernst Haas, som var opptatt av europeisk integrasjon, fremholdt for eksempel at de involverte undergruppene overforer sin lojalitet fra sine respektive nasjonalstater til regimestrukturene (Haas 1958). De samme mekanismene beskrives også i governance-litteraturen. Gerry Stoker hevder for eksempel at "governance handler om autonome selvstyrende aktørnettverk» (Stoker 1999: 18).

Den siste teoretiske forklaringen som trekkes inn i analysen er politisk realisme, som er en tradisjon innenfor IR-teori, og «rational-choice theory» fra politisk teori (f.eks. Elster 1986). Policy forstås da som outcome, eller resultat, av rasjonelle betraktninger. Sentrale beslutningstagere ivaretar nasjonale interesser, og utformingen av nasjonens sikkerhets- og utenrikspolitikk gjenspeiler gjennomtenkte valg til nasjonens beste. Realister erkjenner at utenrikspolitikk ikke nødvendigvis er rasjonell, objektiv og usentimental (Morgenthau 2005: 6-7), men legger likevel rasjonalitet til grunn som en premiss i sine teorier om staters adferd. Ifølge Jon Elster inntreffer tre ulike elementer i en rasjonell beslutningssituasjon. Det ene elementet handler om hvilke alternativer som er gjennomførbare innenfor eksisterende rammer. Det andre knytter seg til kausalitet, altså om hvilke utfall de ulike valgalternativene ventes å få. Det tredje og siste elementet relaterer seg til den subjektive rangeringen av de mulige 
alternativene - utfra hvilke utfall de ventes å få (Elster 1989: 4). Ifølge Thomas Schelling er den rasjonelle forklaringsmodellen så god at «du kan sitte $\mathrm{i}$ godstolen og prøve å forutsi hvordan folk vil oppføre seg utfra hvordan du selv ville ha oppført deg om du var ved dine fulle fem. Du får da, helt gratis, en hel del indirekte empirisk oppførsel» (Archibald 1966: 150). Beslutninger er altså instrumentelle, og ifølge mange av realismens sentrale teoretikere er makt den mest avgjørende faktoren i alt politisk liv (Gilpin 1984).

\section{Drivere bak nordområdesatsingen}

Faktorene som ble vektlagt da nordområdesatsingen tok form i 2005-2006 har vært mange, og oversikten under gir på ingen måte et utfyllende bilde av alle faktorer som medvirket til nordområdesatsingen. Oversikten gir imidlertid et bilde av drivere som var helt sentrale for satsingen, som da var særlig aktuelle og tidsriktige, og som det ble brukt midler og/eller politisk kapital på å adressere.

\section{Olje og gass}

Frem mot 2005, da Stoltenberg II definerte nordområdene som Norges viktigste strategiske satsingsområde, handlet mye av nordområdedebatten om olje og gass. I 2000 publiserte U.S. Geological Survey (USGS) sitt berømmelige anslag, som plasserte 25 prosent av verdens uoppdagede petroleumsressurser nord for polarsirkelen (USGS 2000). Anslaget ble en "game-changer». Orheim-utvalgets offentlige utredning, NOU-en «Mot nord!», som ble bestilt av Utenriksdepartementet året før, viste til - og illustrerte - U.S. Geological Surveys anslag og la betydelig vekt på olje- og gassressursene. Et underkapittel i utredningen fikk den betegnende tittelen «Energi - den nye store drivkraften i nordområdene» (NOU 2003: 86). Da Bondevik II-regjeringen fulgte opp med den aller første nordområdemeldingen i 2005, ble betydningen av olje og gass for nordområdene også vektlagt spesielt:

I dag er mye av oppmerksomheten i nordområdene rettet mot petroleumsressursene. De arktiske områdene antas å inneholde betydelige deler av verdens uoppdagede petroleumsressurser, og globalt rettes søkelyset nå mot nordområdene som en fremtidig stor petroleumsprovins. I et langsiktig perspektiv kan nordområdene således representere Europas viktigste petroleumsprovins. (St.meld. (2004-2005): 11)

Det var særlig USAs etterspørsel etter olje og gass som ble trukket frem som en grunnleggende driver for petroleumsutviklingen i nordområdene. I 2005 importerte USA hele 65 prosent av sitt forbruk av råolje. «Vi står foran en intens lete- og utbyggingsperiode i Barentshavet de nærmeste 10-15 årene, spesielt for å møte USAs økende energibehov,» mente Johan Petter Barlindhaug (Forskningsrådet 2005), en industribygger og en av de mest synlige samfunnsdebattantene i nordområdespørsmål på denne tiden. Også Jonas Gahr Støre, utenriksminister fra høsten 2005, 
beskrev nordområdene som Europas nye energiregion. «Energidimensjonen løfter seg fram som den kanskje viktigste i nordområdene,» fremholdt han (Støre 2005).

Sjtokman og samhandel med Russland

Tidlig på 2000-tallet siktet norsk næringsliv seg for alvor inn på Russland, som var inne $\mathrm{i}$ en voldsom vekst takket være raskt stigende energipriser. Norske selskaper viste særlig interesse for ett enkelt prosjekt, som også må kunne beskrives som en av de viktigste driverne bak nordområdepolitikken på denne tiden. Sjtokman, på russisk sokkel i Barentshavet, skulle utvikles. Feltet skal inneholde 3,9 billioner standardkubikkmeter med gass (Gazprom 2017) og er dermed et av verdens største gassfelt.

Både Hydro og Statoil ville være med å utvikle feltet, men måtte konkurrere med andre internasjonale beilere, som Chevron, Conoco Phillips, Exxon Mobil, Mitsui, Shell, Sumitomo og Total. Den norske regjering forsøkte iherdig å sikre norske selskaper innpass på russisk sokkel, og en rekke bilaterale avtaler ble inngått for å fremme samarbeid. I 2002 underskrev president Vladimir Putin og statsminister Kjell Magne Bondevik en felles erklæring om samarbeid mellom norske og russiske leverandører i regionen. Flere lignende avtaler ble inngått også i 2005. I september 2005 prekvalifiserte den russiske operatøren Gazprom begge de norske selskapene som mulige utbyggingspartnere på Sjtokman sammen med tre andre selskaper.

Stoltenberg II-regjeringen, som tiltrådte like etterpå, la betydelig vekt på et strategisk partnerskap mellom Norge og Russland i utvinningen av olje- og gassressursene. «Vi vil at Barentshavet skal utvikles videre som "et samarbeidets hav", et fredsprosjekt, med norske interesser i samvirke med russiske interesser og - der det er naturlig - med interesser fra vestlige land," sa utenriksminister Jonas Gahr Støre i sin berømmelige tale, Et hav av muligheter - en ansvarlig politikk for nordområdene, som han holdt ved Universitetet i Tromsø i 2005 (Støre 2005). Her lanserte han Barents 2020, som skulle «bli en arena for et nærmere samarbeid med russerne om energiutviklingen i nord». Han gjorde det også klart at norske myndigheter jobbet aktivt for at Hydro og Statoil skulle få innpass på Sjtokman:

Vi ønsker et strategisk energipartnerskap med Russland i nord. Vi ønsker et samarbeid om utvikling av energiressursene, og vi ønsker et utdypet samarbeid for å sikre et utsatt havmiljø og verdifulle fiskestammer. Statoil og Hydro er med blant fem selskaper i siste runde før russerne velger sine samarbeidspartnere til utviklingen av Sjtokmanfeltet. Det er en klok avgjørelse. De norske selskapene har selv posisjonert seg basert på erfaring, teknologisk kompetanse og finansiell styrke. Norske myndigheter støtter dem og vil være tydelige om dette i kontakten med russiske myndigheter. (Støre 2005)

Også to år tidligere la Orheim-utvalget betydelig vekt på næringsutvikling i og samarbeid med Russland. Utvalget merket seg imidlertid at det russerne viste «betydelig skepsis» mot å slippe utenlandske selskaper inn på strategisk viktige områder (NOU 2003: 48). Bondevik II-regjeringens nordområdemelding fra 2005 
fremholdt at innpass i utviklingen av russisk sokkel kunne få store ringvirkninger. «Norsk deltagelse her vil kunne gi ny aktivitet for norske oljeselskaper, leverandørindustrien og det lokale næringsliv i Norge-Norge,» het det (St. meld. 30 (2004-2005): 12-13).

\section{Transarktiske sjøruter}

Mindre sjøis i Polhavet impliserte at det åpnet seg en snarvei mellom Stillehavet og Atlanterhavet. Avstandene mellom havner i Asia og Europa kunne kortes betydelig ned dersom fartøyene seilte gjennom Beringstredet og over Polhavet istedenfor gjennom Suezkanalen eller rundt Kapp det gode håp. «For noen destinasjoner blir avstanden så mye som 50 prosent kortere sammenlignet med rutene som brukes $\mathrm{i}$ dag,» het det i en rapport fra Fridtjof Nansens Institutt som kom ut i 2000 (Ragner 2000). Rapporten, Northern Sea Route Cargo Flows and Infrastructure: Present State and Future Potential, oppsummerte et flerårig forskningsprosjekt finansiert av blant andre Utenriksdepartementet (Skagestad 2014). Orheim-utvalget bemerket i 2003 at med seilbare passasjer gjennom Arktis ville "verdenshandelen kunne revolusjoneres. Her er et fremtidig potensial for ytterligere integrering av Arktis i global handel og økonomi» (NOU 2003: 26).

Også kommersielle aktører ante store muligheter i nye sjøruter og var aktive pådrivere for nordområdesatsingen. I 2006 kjøpte Tschudi Shipping Company hele Sydvaranger AS i Kirkenes, inkludert kaiområdene, som inngikk i selskapets satsing på skipstrafikk langs Den nordlige sjørute. Selskapet skulle senere stifte Senter for nordområdelogistikk (CHNL), som skulle få flere millioner kroner i støtte fra Utenriksdepartementet.

\section{NATOs oppmerksomhet}

Med Russland som forretningsmulighet og partnerland endret også det sikkerhetspolitiske bildet seg. På begynnelsen av 2000-tallet vokste norske myndigheters bekymring for at NATOs nordlige flanke var på vei inn i glemmeboken. Norges relevans i alliansen var sterkt fallende. Avspenning og samarbeid mellom øst og vest, et NATO som utvidet seg $\mathrm{i}$ andre himmelretninger, samt alliansens orientering mot internasjonale operasjoner i fjernere strøk - såkalte «out-of-area» -operasjoner - forsterket inntrykket av at Norges nærmeste allierte heller forbandt sikkerhet og nordområdene med en svunnen kald krig-tid. «NATO har lenge nedtonet nordområdenes militærstrategiske betydning,» bemerket Orheim-utvalget i 2003 (NOU 2003: 85).

«Endret sikkerhetspolitisk oppmerksomhet» ble også et eget underkapittel i den første nordområdemeldingen (St. meld. 30 (2004-2005): 11). "For Norge er det viktig med fortsatt oppmerksomhet fra NATO-land mot nordområdene,» skrev Bondevik II-regjeringen, som viste til at Norge hadde vært vant til «betydelig interesse hos våre allierte» under den kalde krigen. Bondevik II-regjeringen satte følgelig inn et omfattende diplomatisk støt for å trekke alliertes oppmerksomhet tilbake til nordområdene. «Etablering av nordområdedialoger med sentrale vestlige land blir et viktig 
nytt element i norsk nordområdepolitikk,» het det i den samme stortingsmeldingen (St. meld. 30 (2004-2005): ibid. 33).

Behovet for mer oppmerksomhet fra allierte ble også understreket av Stoltenberg II-regjeringens nordområdestrategi fra 2006:

Dette er viktig for å gjøre allierte land kjent med forholdene i nord, samtidig som slik aktivitet er av stor betydning for alliert samvirke $\mathrm{i}$ operasjoner mer generelt. Regjeringen satser på å øke den allierte deltakelsen i militære øvelser og trening i nord. (Regjeringen 2006: 17)

Folkerettslige spørsmål

«De uavklarte folkerettslige spørsmål i nordområdene utgjør en spesiell utenrikspolitisk utfordring,» het det i den første nordområdemeldingen (St. meld. 30 (2004-2005): 6) som Bondevik II-regjeringen la frem i 2005. Meldingen rommet et helt kapittel om folkerettslige utfordringer og var delt inn i underkapitlene Avgrensning av kontinentalsokkel og 200-milssoner $i$ Barentshavet, Kontinentalsokkelens yttergrense utenfor 200 mil og Fiskevernsonen ved Svalbard (St.meld. 30 (2004-2005): 22-24). Orheim-utvalget, som ifølge mandatet ikke skulle vurdere «jurisdiksjonsspørsmål og grunnleggende sikkerhetsinteresser» (NOU 2003: 19), valgte likevel å føye til at en avklart delelinje med Russland ville være «det viktigste enkeltstående tiltaket som må til» for et godt og forpliktende samarbeid med Russland i regionen (NOU 2003: 11, 94). Utenriksminister Jonas Gahr Støre la også stor vekt på at uavklarte spørsmål sto i veien for økonomisk utvikling. «Enda nye muligheter åpner seg når vi får trukket en grenselinje i havet slik det høver seg gode naboer,» sa han i sin første nordområdetale (Støre 2005).

Det ble også lagt ned betydelige ressurser på andre uavklarte folkerettslige spørsmål. For eksempel ble arbeidet med å fastsette yttergrensene for norsk sokkel utenfor 200-milsgrensene høyt prioritert på begynnelsen av 2000-tallet (Pedersen 2003). Norge jobbet særlig iherdig med å kartlegge sokkelskråningen nord for Svalbard, der hvor den faller ned mot det internasjonale dyphavet i polhavsbassenget. Myndighetene hadde en tiårsfrist som rykket stadig nærmere: Norge ratifiserte FNs havrettskonvensjon i 1996 og hadde følgelig frist til 2006 med å presentere sine sokkelkrav for den internasjonale kontinentalsokkelkommisjonen i New York. Norske og danske myndigheter forhandlet på denne tiden også om en maritim grense i havområdene mellom Grønland og Svalbard. Med andre ord: Alle maritime grenser til Norges aller nordligste jurisdiksjonsområder var i spill, enten på forhandlingsbordet eller i kartleggingsfasen og forsvarte følgelig mye oppmerksomhet fra Utenriksdepartementet.

\section{Endrede premisser i nord}

Olje og gass

Premissene for nordområdepolitikken har endret seg betraktelig siden 2006. Gassprisene nær sagt kollapset mot slutten av 2008, fra rundt $\$ 12 /$ MMBtu i juli 2008, 
til under $\$ 3 /$ MMBtu noen måneder senere (Energy Information Administration 2017b), ikke minst som følge av finanskrise og skiferrevolusjonen i USA. I sine ferskete månedsrapporter forventer U.S. Energy Information Administration at prisen vil holde seg rundt eller like over $\$ 3 / M M B t u$ videre inn i 2018. Videre er oljeprisene nesten blitt halvert de siste tre-fire årene, fra rundt $\$ 110$ /fat første halvdel av 2014 til rundt $\$ 60 /$ fat ved utgangen av 2017 (Brent 1. posisjon). USA importerer ikke lenger råolje tilsvarende 65 prosent av sitt forbruk, som i toppåret 2005, men 28 prosent. USA har ikke vært så selvforsynt med petroleum siden 1970 (U.S. Energy Information Administration 2017a), og landet ventes å gå fra å være nettoimportør til nettoeksportør av råolje innen få år (CNN 2016). Nordområdedebattant Johan Petter Barlindhaugs spådommer om at USA og Russland, som henholdsvis kjøper og selger, skulle finne hverandre i Barentshavet, og at Norge skulle ende opp som en utspilt «spurv i tranedans» (Forskningsrådet 2005), virker i dag helt fjern. Ny teknologi, både innen konvensjonell og ikke-konvensjonell produksjon, bidrar til at de påviste oljereservene på verdensbasis stadig vokser. World Energy Council snakker nå heller om at etterspørselen etter olje per capita vil passere en topp før 2030 («peak oil demand") og ser følgelig for seg varlig lave oljepriser (World Energy Council 2016). Dette er et dramatisk brudd med den tidligere "peak oil supply»-logikken, som bygget på forventningen om et sterkt voksende energibehov som sammenfalt med at tilbudet av den ikke-fornybare ressursen raskt ville krympe - og følgelig sende oljeprisen til himmels (Hubbert 1962).

Letevirksomheten i Barentshavet har uansett ikke gitt den uttellingen som Statoil og andre hadde håpet på. De færreste letebrønnene har de siste årene levd opp til produsentenes forventninger (Dagens Næringsliv 2017b). Lønnsomheten i allerede igangsatte pionerprosjekter i nord er også høyst usikker. Overskriftene i dag handler ikke lenger like mye om "Europas nye oljeprovins", men reiser heller spørsmål om det eneste oljeproduserende feltet i den norske delen av Barentshavet, «skandaleprosjektet» (Dagens Næringsliv 2017a) Goliat, i det hele tatt skulle ha vært utbygd (Dagbladet 2017; E24 2017). Allerede i 2015 konkluderte Oljedirektoratet med at feltet kunne forventes å bli «marginalt lønnsomt eller marginalt ulønnsomt» (Olje- og energidepartementet 2017).

Selv om Regjeringen legger opp til et betydelig leteprogram i Barentshavet fremover og har lyst ut rekordmange blokker i området det siste året - og til tross for at Statoil fortsatt investerer betydelig i ny infrastruktur, ikke minst knyttet til Johan Castberg-feltet (Dagens Næringsliv 2017a) - er forventingene til regionen som et slags nytt Midtøsten så godt som forduftet.

Sjtokman og samhandel med Russland

Sjtokman ble lagt på is kort tid etter at gassmarkedet kollapset i 2008. Fra å stå høyt på agendaen når statsoverhoder og statsråder fra Norge og Russland møtes, er gassfeltet blitt en parentes i norsk politikk. I det hele tatt, samhandel med og investeringer i Russland er ikke lenger særlig attraktivt. Telenor, som har vært en av de største 
norske investorene i Russland, har solgt seg kraftig ned i nabolandet. VimpelCom, eller Veon som det heter nå, var et joint-venture mellom Telenor og den russiske oligarken Mikhail Friedman og hans Alfa-gruppe og har vært hjemsøkt av skandaler. Bestikkelser, korrupsjon og søksmål har vært ingredienser i dette russlandseventyret, som også har resultert i utskifting av flere Telenor-topper. Mens Telenor tidligere hadde 33 prosent av aksjene og 43 prosent av stemmene, er selskapets eierandel i VimpelCom nede i 15 prosent etter de siste nedsalgene (Dagens Næringsliv 2017c). Heller ikke i Nordvest-Russland er det lenger attraktivt å etablere seg for norske bedrifter. I dag finnes det knapt en eneste norsk bedrift igjen i Murmansk, til dels på grunn av trakasseringen fra den russiske sikkerhetstjenesten FSB (Nilsen 2017). Sanksjonene som ble satt inn mot Russland etter Ukraina-krisen i 2014, og reaksjonene fra russisk hold, har gjort det både vanskeligere og enda mindre attraktivt for utenlandske bedrifter å investere i landet. Direkteinvesteringene (Foreign Direct Investments) i Russland falt fra \$69 milliarder i 2013 til \$6,8 milliarder i 2015 (Economist 2017). Norges forhold til Russland er endret radikalt, og nabolandet forbindes i dag oftere med mulige trusler enn store forretningsmuligheter (Sverdrup \& Rowe 2015).

\section{Transarktisk skipsfart}

Den nordlige sjørute har vist seg lite egnet for transarktisk skipsfart, til tross for rekordlite sjøis og rekordlange seilingssesonger de siste årene. Isforholdene er fortsatt omskiftelige og gjør seilasene uforutsigbare, noe som er uforenelig med linjetrafikkens forretningsmodell som forutsetter høy regularitet og ankomst ved destinasjonen «just in time». Det vil de sannsynligvis også være den dagen Polhavet blir «isfritt». Fraktratene er ikke høyere enn at det fortsatt er langt mer lønnsomt å være presis enn raskest mulig. Til tross for store russiske investeringer i infrastruktur langs ruten, går den fortsatt gjennom en utsatt del av verden med lite navigasjonshjelpemidler og langt mellom søk- og redningskapasiteter. Deler av sjøruten går gjennom grunne farvann og er derfor uegnet for de største og gjerne mest kostnadseffektive fartøyene. Egnede skip må svare til Den internasjonale sjøfartsorganisasjonens (IMO) polarkode og er langt dyrere i anskaffelse og drift i tillegg til, kostnader for russisk isbrytereskorte og losavgift. Rederiene selv har konkludert med at sjøruten i beste fall er en markedsnisje og viser liten eller ingen interesse for «snarveien» (Lasserre et al. 2016; Lasserre 2014). Utsiktene til internasjonal transarktisk skipsfart langs sjøruten blir ytterligere dempet av at Russland ikke lenger anstrenger seg for å tiltrekke seg fartøyer fra andre land til disse farvannene. President Vladimir Putin har allerede signalisert at utelukkende russiske fartøy bør kunne transportere olje og gass langs sjøruten, dels for å gi et løft til russiske skipsverft (The Independent Barents Observer 2017). Skulle den transarktiske skipstrafikken mot all formodning likevel ta seg betraktelig opp, har den langt på vei falt bort som en driver for dagens norske nordområdepolitikk. Som statsviteren Odd Gunnar Skagestad sier: «Jeg ser for min del ikke noe behov for at dette bør være et prioritert satsingsområde for norske myndigheter»(Skagestad 2014). 
NATOs oppmerksomhet

NATOs nordlige flanke rakk aldri å forsvinne i glemmeboken. I 2008 rykket russiske styrker inn i nabolandet Georgia, og omtrent samtidig lanserte norske myndigheter sitt nærområdeinitiativ for forsvarsministrene i NATO (Hilde \& Widerberg 2010). NATOs strategiske konsept, vedtatt på toppmøtet i Lisboa to år senere, brakte alliansen tilbake til sin kjerneoppgave, nemlig forsvaret av medlemslandenes egne territorier. Norske myndigheter fikk riktignok ikke gjennomslag for en særlig referanse til Arktis eller nordområdene i det strategiske konseptet (Aftenposten 2011), men sa seg svært godt fornøyd med at «in-area» kjerneoppgaver var brakt inn i strategidokumentet og satt øverst på alliansens dagsorden.

Russlands annektering av Krimhalvøya i 2014, og de påfølgende vestlige sanksjonene mot landet, har ytterligere forsterket spenningen mellom øst og vest. NATO kan i dag sies å være særlig opptatt av Russland og egne flanker, inkludert den nordlige. Langs den østlige flanken har NATOs militære nærvær vært forsterket siden 2016 i form en fremskutt kollektiv kompanistridsgruppe - såkalt Enhanced Forward Presence (eFP) - som skal avskrekke Russland og berolige alliansepartnerne Estland, Latvia, Litauen og Polen.

I nord er alliansen også tilbake, kanskje sterkere enn noen gang. NATO-øvelsen Trident Juncture, som er en av alliansens aller største øvelser, blir høsten 2018 lagt til Norge og tilstøtende luft- og sjøområder. Rundt 35.000 soldater, 130 fly og 60 fartøyer vil delta på det som defineres som en High Visibility Exercise (Forsvaret 2018). Viktige alliansepartneres oppmerksomhet mot nord gjenspeiles også i at U.S. Marine Corps (USMC) nå har en rotasjonsstyrke på norsk jord (Forsvaret 2017), en sterk økning i antallet amerikanske ubåter som frekventerer Barentshavet (The Independent Barents Observer 2018) og den kraftige oppbyggingen og moderniseringen av USA-støttet overvåkings- og etterretningskapasitet i Nord-Norge og Barentshavet.

Norge trenger ikke lenger en nordområdesatsing for å fange NATO-alliertes oppmerksomhet eller synliggiøre de sikkerhetspolitiske og militærstrategiske utfordringene som Russland utgiør i nord.

Folkerettslige spørsmål

Mange av de folkerettslige utfordringene som ble vektlagt da nordområdesatsingen tok form, har siden falt bort. Utenriksdepartementet skriver selv på sine egne nettsider:

Avgrensningsavtalen med Russland løste Norges desidert største og viktigste avgrensningsspørsmål. Med denne og andre avtaler eller forståelser om avgrensning har Norge for alle praktiske formål avklart de maritime avgrensningsspørsmål i nord. (Utenriksdepartementet 2014)

To av de tre utfordringene som den første nordområdemeldingen fra 2005 trakk frem, er definitivt løst. I november 2006 sendte Norge inn sitt krav på kontinentalsokkelområder utenfor 200 nautiske mil til Kontinentalsokkelkommisjonen i New 
York (CLCS) (Jensen 2010; Pedersen \& Henriksen 2009). Drøye to år senere, i mars 2009, anbefalte kommisjonen hvor yttergrensene for norsk kontinentalsokkel skulle trekkes (CLCS 2009), som dermed kunne fastsettes av norske myndigheter en gang for alle. Grensene anses i dag for å være "endelige og bindende», $i$ henhold til FNs havrettskonvensjons artikkel 76(8) (Jensen 2010; Pedersen \& Henriksen 2009). Som en ekstrabonus ble dessuten Danmark og Norge i 2006 enige om en delelinje i Framstredet, mellom Grønland og Svalbard.

Det største gjennombruddet for norske myndigheter var imidlertid avtalen med Russland om en delelinje i Barentshavet og Polhavet. Avtalen ble signert i 2010 og ratifisert av begge land året etter. Med avtalen ble et tidligere omstridt område på anslagsvis 175000 kvadratkilometer delt i to mellom Norge og Russland. Den tidligere gråsoneavtalen ble overflødig, og jurisdiksjonsforholdene avklart. Daværende statsminister Jens Stoltenberg omtalte avtalen som den viktigste saken i 2010. «En 40-årig konflikt er løst,» oppsummerte han under en pressekonferanse på tampen av året (NTB 2010).

Den største utfordringen i nordområdene var løst. Ingen av Norges maritime grenser er lenger omstridt. En driver for nordområdesatsingen har forsvunnet.

\section{Nordområdesatsingen lever videre}

Allerede i 2008 fremholdt Geir Hønneland og Leif Christian Jensen at «i skrivende stund er kanskje det mest interessante spørsmålet om nordområdeeuforien er på hell» (Hønneland \& Jensen 2008). Men engasjementet lever videre, til tross for at faktorene som resulterte i nordområdesatsingen og skapte eufori på begynnelsen av 2000-tallet har mistet sin betydning. Nordområdene har overlevd både som begrep og satsingsområde.

Denne artikkelen skisserer tre forklaringer på hvordan nordområdesatsingen har kunnet holdes gående, til dels uavhengig av sentrale faktorer som bidro til dens tilblivelse. Den første forklaringen handler om symbolpolitikk; den andre bygger på institusjonalisme; og den siste støtter seg på politisk realisme.

Nordområdesatsingen som symbolpolitikk?

"Nordområdene", som hadde en påfallende vag betydning og uklar geografisk adresse, traff en nerve i folket rundt år 2005 og skapte en voldsom forventning, særlig i den nordligste landsdelen. "Alle» meldte seg på og ville være en del av «Norges viktigste strategiske satsingsområde». Urfolk, lokalsamfunn langs kysten, næringslivet, utdanningsinstitusjoner, forskere og utposter definerte seg inn i begrepet og satsingen. Det skapte en tro på en ny giv i nord. Både nordområdebegrepet og -satsingen minner således om Murray Edelmanns definisjon av condensation symbols: De appellerer til følelser og kan skape inntrykk av at vanskelige og sammensatte utfordringer blir håndtert av politiske beslutningstagere. Realitetene i satsingen har samtidig vært relativt beskjedne, iallfall målt i kroner over statsbudsjettene. Flere fremholdt 
at nordområdesatsingen egentlig bare var ordinære budsjettposter i forkledning (Pedersen 2011), noe som underbygger symbolforklaringen.

Nordområdene som begrep har dessuten egenskaper som Edelmann mener kjennetegner effektfullt politisk språk. Det betyr ulike ting for ulike grupper, samtidig som det sammenfatter et bredt saksfelt som berører mange. Odd Gunnar Skagestad ser ut til å helle mot en slik forklaring i sine analyser av satsingen. «Etter mitt syn må nordområdesatsingen først og fremst betraktes som et politisk motivert retorisk grep. Fordi nordområdene er blitt et honnørord, er det viktig for politikerne å vise at dette er noe som står på dagsorden og at de selv er på banen,» hevder han (Skagestad 2014). Begrepet og satsingen fortsetter å skape forventninger selv den dag i dag og vil leve videre så lenge det engasjerer «massene». Ifølge Edelmann er det ikke dermed sagt at beslutningstagerne forsøker å bedra folk med symbolpolitikk - de bare spiller ut sin politiske rolle.

Nordområdesatsingen opprettholder seg selv?

Strukturene som nordområdesatsingen har skapt, formet og/eller finansiert, som for eksempel nordområdeseksjonen ${ }^{1}$ i Utenriksdepartementet, Nordområdesenteret i Bodø, Framsenteret ${ }^{2}$ i Tromsø og den årlige gigantkonferansen Arctic Frontiers, redefinerer sine egne eksistensgrunnlag løpende og sikrer fornyet finansiering, slik at politikkområdet overlever, på samme måte som internasjonale regimer «lever sitt eget liv, upåvirket av de grunnleggende kausalfaktorene som førte til at de ble skapt i utgangspunktet", for å låne et regimesitat fra teoretikeren Stephen Krasner (1983a).

Nettverkene som er blitt opprettet av nordområdesatsingen vil stadig lete, finne og påpeke de største mulighetene og utfordringene i regionen. Når opprinnelige drivere faller bort, leter de etter nye. Konkrete utfordringer og muligheter erstattes kanskje da med mer generelle og vage referanser til regionens betydning. Som en illustrasjon: I invitasjonen til seminaret «Nordområdene nå» i 2017, oppsummerte arrangørene Kirkeneskonferansen, Nordområdesenteret og Arctic Frontiers regionens betydning slik:

Nordområdene står i sentrum for norsk politikk. Vår utenrikspolitikk, sikkerhet og økonomi dreier seg i stor grad om utviklingen i nord. Omstillingen i norsk økonomi har gjort utviklingsmulighetene i nord særlig viktig for hele landet. Derfor preges livet i nord av storpolitikk mer enn noe annet sted. (Facebook 2017)

Det levnes ingen tvil om at arrangørene, som altså selv er tre barn av nordområdesatsingen, mener nordområdene forblir viktig - riktignok på et heller uklart grunnlag. Men med daværende utenriksminister Børge Brende som arrangementets trekkplaster, måtte det være viktig.

\footnotetext{
${ }^{1}$ Formelt: Seksjon for nordområdene, polarsaker og ressurser (Section for the High North, Polar Affairs and Marine Resources), som er en del av Sikkerhetspolitisk avdeling.

${ }^{2}$ Formelt: FRAM - Nordområdesenter for klima- og miljøforskning.
} 
Heri ligger det en parallell til institusjonalisme, inkludert internasjonal regimeteori. Aktører, som inngår i og nyter godt av nordområdesatsingen, kan tenkes å overføre sin lojalitet til satsingen og dens videre eksistens, slik byråkrater fra ulike land kan komme til å knytte lojalitetsbånd til regimene de er representert i (Haas 1958). Regimer - og nordområdesatsingen - begynner da å leve sitt eget liv. Nordområdesatsingen styrker seg selv, slik internasjonale regimer opprettholder sin egen integreringsprosess og gjør seg selv mer uavhengig av medlemslandene. I så fall kan nordområdesatsingen begynne å ligne på et autonomt selvstyrende aktørnettverk, for å låne en beskrivelse fra governance-teorien (Stoker 1999).

Den rasjonelle nordområdesatsingen?

Denne studien er ikke uttømmende og har ikke tatt med alle faktorer som bidro til at nordområdene gikk til topps på den politiske dagsordenen på midten av 2000-tallet. Den rasjonelle forklaringen kan derfor være at faktorer som er utelatt fra studien alene kan forsvare det vedvarende engasjementet - eventuelt at det er kommet til nye faktorer som kan rettferdiggjøre fortsatt nordområdesatsing.

Dette er selvfølgelig en plausibel forklaring. Siden 2005 har vi hatt Det internasjonale polaråret (som varte i to år, fra 2007 til 2009) og fått ny og omfattende kunnskap om hvordan Arktis påvirkes av klimaendringer og forurensing fra hele verden. Frykten for et kappløp om ressursene i Polhavet vokste da Russland i 2008 sendte en ubåt for å plante det russiske flagget på polpunktet, et trekk som provoserte enkelte arktiske land så vel som flere ikke-arktiske land (Borgerson 2008). Interessen for regionen blant ikke-arktiske land er betydelig større nå enn på begynnelsen av 2000-tallet, noe som gjenspeiler seg i hvilke land som har søkt observatørstatus i Arktisk råd siden den gang. Ikke minst har forholdet mellom Russland og Vesten endret seg radikalt etter at russerne annekterte Krimhalvøya i 2014. Det åpenbare folkerettsbruddet og de påfølgende sanksjonene har radert vekk tilliten mellom partene, og mistilliten strekker seg også opp og inn i nordområdene. Russlands militære styrker tar samtidig stadig mer plass i nord. Infrastrukturen rustes opp langs hele den russiske nordkysten, og militærøvelsene blir både større og hyppigere. Påstanden om at noen av Norges fremste utenriks- og sikkerhetspolitiske utfordringer fortsatt ligger i nord, er ikke spesielt kontroversiell.

Hvis dette er den mest dekkende forklaringen, kunne det være fristende å oppsummere dagens nordområdesatsing med en omskriving av tittelen på Henning Kvitnes \& The Young Lords debutplate «Same Shit - New Wrapping». Vi snakker da om nordområdesatsingen som «new shit, same wrapping»: Det er bare innpakningen som holder seg nokså konstant.

\section{Avslutning}

Innholdet i begrepet "nordområdene» og nordområdesatsingen er radikalt endret siden 2005. Mens den strategiske satsingen på begynnelsen av 2000-tallet i stor grad 
var relatert til maritime muligheter - for utvikling av en ny og betydelig energiprovins, russisk markedsadgang, avklaring av delelinjespørsmålet, petroleumssamarbeid og transarktisk skipsfart - fikk politikkområdet de påfølgende årene et langt større innenrikspolitisk preg. Den strategiske satsingen ga utover på 2000-tallet forventinger om OL i Tromsø, ny nordnorsk infrastruktur og generell distriktsutvikling. I dag står ulike trusler i og rundt Barentshavet sentralt i den nasjonale nordområdepolitikken - trusler mot økosystemer fra miljøgifter og som følge av klimaendringer; trusler fra et mer selvhevdende Russland, som har bygd opp en voldsom militær kapasitet i nord og som i 2014 annekterte deler av nabolandet Ukraina.

Til tross for at innholdet til dels er nytt har altså nordområdene bestått som begrep og satsingsområde. Denne artikkelen har utforsket ulike forklaringer på hvordan satsingen har kunnet overleve driverne som sto helt sentralt da den ble til:

1) Symbolpolitikk: Nordområdene er et sterkt og innarbeidet symbol som vekker engasjement og skaper forventninger. Det er tilstrekkelig diffust til å være svært virkningsfullt politisk språk - «nordområdene» kan bety både Arktis, Barentshavet, Nord-Norge, eller Norges umiddelbare nærområder i nord. Det kan vise både til innenriks- og utenrikspolitiske muligheter - og det treffer ulike deler av befolkningen på ulike måter. Symbolbruken inngår i den politiske rollen som beslutningstagere spiller overfor befolkningen.

2) Institusjonalisme: Nordområdesatsingen har skapt en rekke strukturer som løpende legitimerer seg selv.Vi snakker her for eksempel om omfattende og fokuserte forskningsstrukturer, som Nordområdesenteret i Bodø og Framsenteret i Tromsø, den årlige Arctic Frontiers-konferansen og organisasjonsstrukturer innad i departementer, inkludert nordområdeseksjonen i Utenriksdepartementet. Aktørene som inngår i strukturene vil gjerne fremholde at nordområdene er viktig for å sikre sin egen eksistens, men begrunnelsen de gir vil kunne endres over tid, og kanskje få et mer generelt eller vagt preg ettersom de opprinnelige driverne faller bort.

3) Rasjonalitet: De politiske mulighetene og utfordringene som Norge står overfor krever en politisk nordområdesatsing, omtrent slik den foreligger per dags dato. Dette fremstår for myndighetene som det høyest rangerte av de ulike alternativene som er blitt vurdert. Vurderingen er rasjonell og kan forklares med de kausalfaktorene som eksisterer i dag. I den grad "gamle» utløsende faktorer har falt bort, har nye kommet til.

Det er nok en sannhet $i$ alle de tre forklaringene.

\section{Referanser}

Aftenposten (2011) «Kampen Norge tapte» 26.07.11.

Archibald, Kathleen (1966) Strategic Interaction and Conflict: Original Papers and Discussion. Berkeley: Institute of International Studies of the University of California.

Arthur, Brian (1989) «Competing Technologies, Increasing Returns and Lock-In by Historial Events», Economic fournal, 97: 642-665.

Borgerson, Scott (2008) "Arctic Meltdown: The Economic and Security Implications of Global Warming», Foreign Affairs 87(2): 63-77.

Bourdieu, Pierre (1977) Outline of a Theory of Practice. Cambridge: Cambridge University Press. 


\section{Torbjørn Pedersen}

Dagbladet (2017) «Oljedirektoratet har plutselig funnet tallene: De viser at Goliat ikke blir lønnsom for Norge» 14.11.2017.

Dagens Næringsliv (2017a) «Bygger ut for 50 milliarder» 05.12.2017.

Dagens Næringsliv (2017b) «Korpfjell-funn ikke lønnsomt» 29.08.2017.

Dagens Næringsliv (2017bc) «Telenor gjør seg ferdig med nedsalget i Vimpelcom» 20.09.2017.

Departementene (2009) Nye byggesteiner $i$ nord: Neste trinn $i$ Regjeringens nordområdestrategi. Tilgjengelig på https://www.regjeringen.no/globalassets/upload/ud/vedlegg/nordomradene/byggesteiner_nord090323_2. pdf. Lesedato 14.11.2017.

Departementene (2017) Nordområdestrategi: Mellom geopolitikk og nceringsutvikling. https://www.regjeringen.no/ contentassets/fad46f0404e14b2a9b551ca7359c1000/nord_strategi_2017_ny.pdf

E24 (2017) «Goliat ble utsatt etter notat som spådde marginal lønnsomhet» 16.11.2017.

The Economist (2017) «America's new economic sanctions may hurt Russia's recovery» 05.08.2017.

Energy Information Administration (2017a) «How much oil consumed by the United States comes from foreign countries?». Tilgjengelig på https://www.eia.gov/tools/faqs/faq.php?id=32\&t=6. Lesedato 04.04.2017.

Energy Information Administration (2017b) «Henry Hub Natural Gas Spot Price». Tilgjengelig på https:// www.eia.gov/dnav/ng/hist/rngwhhdd.htm. Lesedato 29.11.2017.

Forskningsrådet (2005) «Norge kan lett bli en spurv i tranedans!». Tilgjengelig på https://www.forskningsradet. no/no/Nyheter/_Norge_kan_lett_bli_en_spurv_i_tranedans/1236685417782. Lesedato 07.12.2017.

Forsvaret (2018) «Trident Juncture». Tilgjengelig på https://forsvaret.no/fakta/aktivitet/ovelser/trident-juncture. Lesedato 14.03.2018

Forsvaret (2017) «U.S. Marines har landet i Norge». Tilgjengelig på https://forsvaret.no/aktuelt/us-marinesankom-vaernes. Lesedato 16.01.2017

Gazprom (2017) «Shtokmanovskoye field». Tilgjengelig på http:/www.gazprom.com/about/production/ projects/deposits/shp/. Lesedato 29.11.2017.

Gilpin, Robert (1984) «The Richness of the Tradition of Political Realism», International Organization, 38(2): 287-304.

Haas, Ernst (1958) The Uniting of Europe: Political, Social, and Economical Forces 1950-1957. Notre Dame: University of Notre Dame Press.

Harsem, Øistein, Arne Eide \& Knut Heen (2011) «Factors Influencing Future Oil and Gas Prospects in the Arctic", Energy Policy, 39(12): 8037-8045.

Hilde, Paal \& Helene Widerberg (2010) «NATOs nye strategiske konsept og Norge», Norsk Militcert Tidsskrift, $4 / 10-20$.

Hubbert, King (1962) «Energy Resources», National Academy of Sciences, Publication 1000-D: 81-83.

Hønneland, Geir (2017) «Norway and the High North: Foreign Policy Strategies Since the Cold War», Current Politics and Economics of Europe, 28(1): 31-54.

Hønneland, Geir \& Leif Christian Jensen (2008) Den nye nordområdepolitikken: Barentsbildere etter årtusenskiftet. Bergen: Fagbokforlaget.

Hønneland, Geir \& Lars Rowe (2010) Nordområdene - hva nå? Trondheim: akademisk forlag.

The Independent Barents Observer (2018) «Nuclear Submarines Inshore Norway 3 to 4 Times Monthly» 27.01.2018.

The Independent Barents Observer (2017) «Putin Nationalizes Arctic Petroleum Shipment» 17.11.2017.

Jacobsen, Rolf (1985) Nattåpent. Oslo: Gyldendal.

Jensen, Øystein (2010) "Towards Setting the Outer Limits of the Continental Shelf in the Arctic: On the Norwegian Submission and Recommendations of the Commission». I Davor Vidas (red.) Law, Technology and Science for Oceans in Globalisation: IUU Fishing, Oil Pollution, Bioprospecting, Outer Continental Shelf. Leiden: Martinus Nijhoff Publishers.

Krasner, Stephen (1983a) «Regimes and the Limits of Realism». I Stephen Krasner (red.) International Regimes. Ithaca: Cornell University Press.

Krasner, Stephen (1983b) «Structural Causes and Regime Consequences». I Stephen Krasner (red) International Regimes. Ithaca: Cornell University Press.

Lasserre, Frederic (2014) «Case Studies of Shipping Along the Arctic Routes. Analysis and Profitability Perspectives for the Container Sector", Transportation Research, 66: 144-161.

Lasserre, Frederic et al. (2016) «Polar Super Seaways? Maritime Transport in the Arctic: An Analysis of Shipowners' Intentions II", Fournal of Transport Geography, 57(6): 105-114.

Lasserre, Frederic \& Sebastien Pelletier (2011) «Polar Super Seaways? Maritime Transport In the Arctic: An Analysis of Shipowners' Intentions", fournal of Transport Geography, 19(6): 1465-1473.

Liebowitz, Stan \& Stephen Marolis (1995) «Path Dependence, Lock-In, and History», fournal of Law, Economics and Organization, 11(1): 205-226. 
Lunde, Leiv, Jian Yang \& Iselin Stensdal (red.) (2015) Asian Countries and the Arctic Future. Singapore: World Scientific Publishing.

Marquis, Christopher \& András Tilcsik (2003) «Imprinting: Toward a Multilevel Theory», The Academy of Management Annals, 7(1): 193-243.

Moe, Arild (2015) «International Use of the Northern Sea Route: Trends and Prospects». I Lunde, Leiv, Jian Yang \& Iselin Stensdal, (red.) (2015) Asian Countries and the Arctic Future. Singapore: World Scientific Publishing.

Moe, Arild (2014) «The Northern Sea Route: Smooth Sailing Ahead?», Strategic Analysis, 38(6): 784-802.

Nilsen, Thomas (2017) «Barentsrådsmøte i skyggen av FSB», Nordlys, 17.10.2017.

NOU (2003) Mot nord! Utfordringer og muligheter i nordområdene. Utenriksdepartementet og tilgjengelig på https:// www.regjeringen.no/no/dokumenter/nou-2003-32/id149022/sec1 Norsk Offentlig Utredning 2003: 32.

Olje- og energidepartementet (2017) "Lønnsomhetsberegninger for Goliat», Tilgjengelig på https://www. regjeringen.no/no/aktuelt/lonnsomhetsberegninger-for-goliat/id2578892/. Lesedato 14.11.2017.

Pedersen, Torbjørn (2011) «Nordområdesatsingen: Realitet eller retorikk?» i Jentoft, Svein et al. (red.) Hvor går Nord-Norge? Tidsbilder fra en landsdel i forandring. Orkana Forlag: 271-280.

Pedersen, Torbjørn (2003) «Vil kreve sokkelen under Nordpol-isen», Svalbardposten 55(9), 28.02.2003.

Pedersen, Torbjørn \& Tore Henriksen (2009) «Svalbard's Maritime Zones: The End of Legal Uncertainty?», International fournal of Marine and Coastal Law, 24(1): 141-161.

Rowe, Elena (2014) "Arctic Hierarchies? Norway, Status and the High North", Polar Record, 50(1): 72-79.

Skagestad, Odd Gunnar (2017) «Nordområdene 6.0 - Ringen sluttet?», Minerva, 21.05.2017. Tilgjengelig på https://www.minervanett.no/nordomradene-6-0-ringen-sluttet/. Lesedato 14.11.2017.

Skagestad, Odd Gunnar (2014) «Norsk og internasjonal politikk i "Nordområdene" - historikk og aktuelle utfordringer». Foredrag for Generaladvokatembetet, 10.10.2014. Tilgjengelig på http://ogskagestad.net/ NordomrGeneraladvOkt14.pdf. Lesedato 14.11.2017.

Skagestad, Odd Gunnar (2009) «Nordområdene ("The High North") - et elastisk begrep", Norsk Militert Tidsskrift, 179(2-3).

Solberg-regjeringen (2013) «Politisk plattform for en regjering utgått av Høyre og Fremskrittspartiet» [«Sundvollen»]. Sundvollen, 07.10.2013. https://www.regjeringen.no/no/dokumenter/politisk-plattform/ id743014/. Lesedato 14.11.2017.

St.meld. nr. 30 (2005-2005) Muligheter og utfordringer i nord. Oslo: Utenriksdepartementet.

St.meld. nr. 15 (2008-2009) Interesser, ansvar og muligheter: Hovedlinjer $i$ norsk utenrikspolitikk. Oslo: Utenriksdepartementet.

Stoker, Gerry (1998) «Governance as Theory: Five Propositions», International Social Science fournal, 155: 17-28.

Stoltenberg II-regjeringen (2009) «Politisk plattform for flertallsregjeringen utgått av Arbeiderpartiet, Sosialistisk Venstreparti og Senterpartiet 2009-2013" [ [Soria Moria II»], Oslo, 07.10.2009. Tilgjengelig på http://www.regjeringen.no/upload/SMK/Vedlegg/2009/Ny_politisk_plattform_2009-2013.pdf. Lesedato 14.11.2017.

Stoltenberg II-regjeringen (2005) «Plattform for regjeringssamarbeidet mellom Arbeiderpartiet, Sosialistisk Venstreparti og Senterpartiet 2005-09» [«Soria Moria II»], Oslo, 13.10.2005. Tilgjengelig på http://www. regjeringen.no/upload/SMK/Vedlegg/2005/regjeringsplatform_SoriaMoria.pdf. Lesedato 14.11.2017.

Støre, Jonas Gahr (2008) Å gjøre en forskjell: Refleksjoner fra en norsk utenriksminister. Oslo: Cappelen Damm.

Sverdrup, Ulf \& Elena Wilson Rowe (2015) «Norway is re-thinking its Russian Relations», Europe's World. Tilgjengelig på https://www.friendsofeurope.org/views/norway-re-thinking-russian-relations. 110-111. Lesedato 14.11.2017.

U.S. Geological Survey (2000) «U.S. Geological Survey World Petroleum Assessment 2000: Description and Results", Data Series 60. Tilgjengelig på https://pubs.er.usgs.gov/publication/ds60. Lesedato 14.11.2017.

Utenriksdepartementet (2006) «Regjeringens nordområdestrategi». Tilgjengelig på https://www.regjeringen. no/globalassets/upload/kilde/ud/pla/2006/0006/ddd/pdfv/302927-nstrategi06.pdf. Lesedato 14.11.2017.

Utenriksdepartementet (2017) «Fortsatt satsing i nord». Pressemelding 12.10.2017. Tilgjengelig på https:// www.regjeringen.no/no/aktuelt/budsjett2018_nord/id2574901/. Lesedato 14.11.2017.

Utenriksdepartementet (2014a) Nordkloden. Statusrapport. Tilgjengelig på https://www.regjeringen.no/ contentassets/23843eabac77454283b0769876148950/nordkloden_rapport-red.pdf. Lesedato 14.11.2017.

Utenriksdepartementet (2014b) «Kontinentalsokkelen: Spørsmål og svar». Tilgjengelig på https://www. regjeringen.no/no/tema/utenrikssaker/folkerett/kontinentalsokkelen-sporsmal-og-svar/id448309/. Lesedato 14.11.2017.

World Energy Council (2016) «World Energy Scenarios: The Grand Transition». Tilgjengelig på https://www. worldenergy.org/wp-content/uploads/2016/10/World-Energy-Scenarios-2016_Full-Report.pdf. Lesedato 14.11.2017. 


\begin{abstract}
English
In 2005 the Norwegian government defined the High North as a top priority policy area based on several causal factors, or drivers. Since then, many of these drivers have dwindled away. Today hardly anyone speaks about the High North as "Europe's most important petroleum province», as policymakers did back in 2005. The then-promising Shtokman gas field that Norwegian companies sought access to has since been shelved. Trans-Arctic shipping has flopped. NATO partners did not forget Russia and the alliance's northern flank. And most of the outstanding jurisdictional issues that Norway was a party to back then have since been resolved. Still, the High North remains a top policy priority to the Norwegian government, hence seemingly surviving many of the causal factors that defined the initiative in the first place. This article presents three theory-inspired explanations as to why: 1) The High North Policy is a condensation symbol maintained by the elites as it reassures and engages the audiences; 2) the High North policy has created self-preserving structures that allows the policy area to practically assume a life of its own, not unlike international regimes; and 3) the continuous priority can be explained rationally and instrumentally by other and/or new causal factors.
\end{abstract}

Keywords: Arctic $\cdot$ international regimes $\cdot$ foreign policy $\cdot$ Norway $\cdot$ symbolic politics 